\title{
SEVERE THROMBOSIS OF ABDOMINAL AORTA WITH DISTAL EMBOLISM AS THE ONLY CLINICAL MANIFESTATION OF COVID-19 INFECTION
}

\author{
IVANA ŠTULA ${ }^{1,2,3}$, MAJA MARINOVIĆ GUIĆ ${ }^{1,3}$, SANJA LOVRIĆ KOJUNDŽIĆ'1,2,3, JASENKA GABRIĆ
}

\begin{abstract}
COVID-19 infection usually presents with respiratory symptoms and fever however several unusual initial presentations of this infection were reported in literature. We report a case of arterial thrombosis as a presenting features of this disease without any other COVID-19-related symptoms. This might lead to delayed COVID-19 diagnosis and isolation of suspected patient causing epidemiologic consequences and increased risk of transmission of the virus inside the hospital in time of pandemic unless timely recognized.
\end{abstract}

Keywords: COVID-19, ARTERIAL THROMBOSIS, AORTA, EMBOLISM

\section{INTRODUCTION}

COVID-19 infection usually presents with respiratory symptoms and fever, however there are several unusual extrapulmonary and atypical initial presentations of COVID-19 infection reported (1). Recent literature has shown that SARS-CoV-2 causes endothelial dysfunction leading to thrombosis mostly venous (2). Arterial thrombosis occurs rarely, usually in severe COVID-19 patients (2-6).

\section{CASE REPORT}

A sixty-year-old female patient was admitted to the hospital because of acute onset of pain in the right leg and foot with cramping. A week before admission she was treated for urinary infection. Her husband had a cold ten days prior, but the SARS-CoV-2 test was not performed, and she had no known contact

\footnotetext{
${ }^{1}$ University of Split,

Department of Health Studies

${ }^{2}$ University of Split, School of Medicine

${ }^{3}$ University Hospital of Split

Address:

Sanja Lovrić Kojundžić, MD, PhD

University Hospital of Split

21000 Split, Spinčićeva 1

E-mail: lovric.sanja@gmail.com
}

with a confirmed SARS-CoV-2 infected person. Laboratory tests performed revealed thrombocytosis $514 \times 10^{9} / \mathrm{L}, \mathrm{C}$ reactive protein (CRP) of $56.2 \mathrm{mg} / \mathrm{L}$, prothrombin time (PT) of 0.57 , lactate dehydrogenase (LDH) was $293 \mathrm{U} / \mathrm{L}$ and D-dimer level was $4.26 \mathrm{mg} / \mathrm{L}$. An angio-CT scan performed upon admission identified free-floating abdominal aorta thrombus causing near-complete occlusion of its lumen (Figure 1). Minimal aortic wall calcification in the aortoiliac segment and lack of collaterals indicated acute occlusion. Distal embolism of both deep femoral arteries and the right popliteal artery were also present (Figure 2). The patient had no previous severe comorbidities or known cardiovascular risk factors that could have caused the arterial embolisms.

The preoperative chest X-ray showed signs of bilateral peripheral opacities consistent with viral pneumonia, with $97 \% \mathrm{O}_{2}$ saturation at admission. Although our patient had no fever, respiratory or any other COVID-19-associated symptoms, routine preoperative polymerase chain reaction (PCR) test of the throat and nasopharyngeal swab came positive. The patient underwent endovascular thrombectomy with the retrieval of a large acute thrombus, re- sulting in significant clinical and radiological improvement. She was also treated with anticoagulants. Control angio-CT showed a complete resolution of aortic thrombus. There was no fever or respiratory symptoms neither prior to development of thrombosis nor during the hospitalization period. She had $\mathrm{O}_{2}$ saturation 95\% during hospitalization (normal values) and was discharged with clinical improvement.

\section{DISCUSSION}

It is well known that patients with COVID-19 may have coagulation abnormalities (1). Recently several studies regarding arterial embolism have been published (2-8). Cantador reported a $1 \%$ incidence of systemic arterial thrombotic events, most of them were presented as ischemic stroke (3). In that study only three patients developed acute lower limb ischemia and all of them had severe COVID-19 with bilateral pneumonia (3). Most of the COVID-19 patients who later presented with thromboembolic complications had an onset of severe respiratory symptoms before acute ischemia and thrombosis could be explained by accompanied hypoxia as an emerging cofactor in the thrombosis stimulation $(3,4,6,7,9)$. 


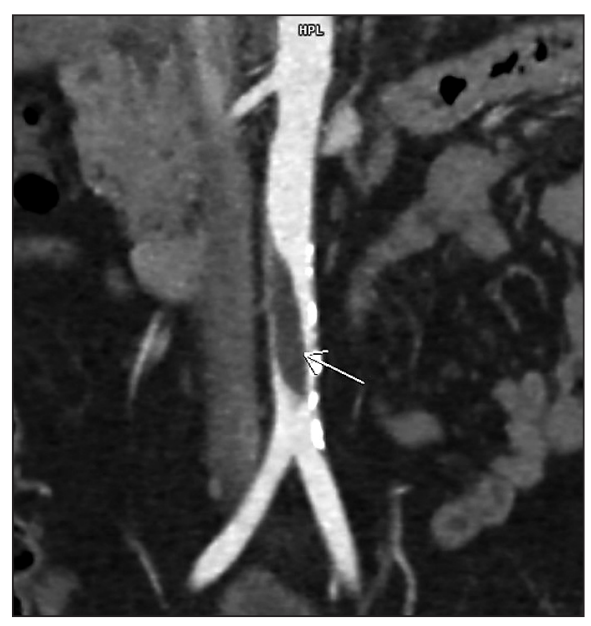

Figure 1.

CT angiography of abdominal aorta:

Multiplanar reconstruction in coronal plane shows a large intraluminal filling defect of the abdominal aorta illustrating extensive freefloating aortic thrombus (arrow).

Among the COVID-19 patients with acute leg ischemia, there were mostly thromboembolic events of the femoral or popliteal artery with frequent history of cardiovascular risk factors $(3,4)$. Cases like ours, with large arterial thrombosis that nearly occluded aorta with massive peripheral embolic occlusion on both legs, were rare, especially in patients without previous cardiovascular disease or risk factors $(10,11)$. Vulliamy and al reported two cases of major occlusive arterial events in patients with confirmed symptomatic COVID-19 who did not have previous peripheral artery disease, but they developed respiratory symptoms before the arterial thrombosis (6). A large thrombus burden and involvement of proximal vessels were noticed in the study of Goldman et al (12). In their study the ischemic leg symptoms were initial symptoms in five patients; however, it is not clear whether these patients developed COVID-19 symptoms afterwards during hospitalization.

As far as we know the available literature reported respiratory symptoms either before or after aortic thrombosis onset. However, our patient never manifested any respiratory symptoms or fever, and she had a large thrombus burden without a history of known atherosclerosis, prothrombotic disease or atrial fibrillation. The pathogenesis of hypercoagulability in COVID-19 is still unclear. It

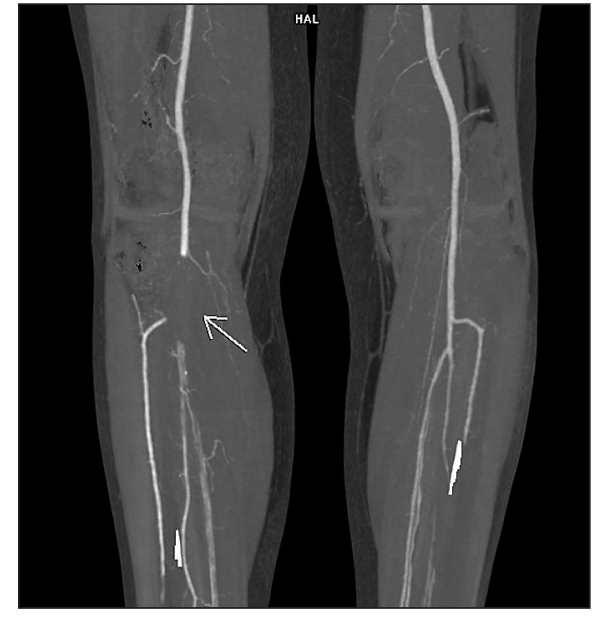

Figure 2.

CT angiography of peripheral arteries. Coronal MIP reconstruction shows thromboembolic occlusion of both deep femoral arteries (A, arrows) and occlusion of the right popliteal artery ( $B$, arrow).

seems that there is direct SARS-CoV-2 viral invasion of endothelial cells that could contribute to clot formation (2). Platelets have a major role in thrombosis which is one kind of defence from pathogens recently termed the "immunothrombosis" (9). Although platelets engulf certain viruses such as HIV or $\mathrm{HCV}$, the immunothrombosis is likely for bacterial infections but less probable for viral infections (9).

Increased platelet count was frequently reported in the COVID-19 patients, especially compared to other coronavirus infections $(7,8,13)$. Although the COVID-19 patients can have high, normal, or low platelet count, thrombocytopenia appears to predict the severity of COVID-19 infection (13). It is well known that an arterial thrombus is the characteristically platelet-rich thrombus formed around ruptured atherosclerotic plaques or damaged endothelium. Progression of thrombus is determined by endothelium and through degradation of fibrin which can explain large thrombus and elevated levels of D-dimer in the COVID-19 patients $(9,12,14)$. Our patient had a high Ddimer value which can be expected due to large acute clots. It is reported that the elevation of D-dimer is correlated with severe COVID-19 infection (14).

If the endothelial injury is present together with thrombocytosis, a for- mation of the large arterial thrombus can occur. Although it seems that the incidence of arterial thrombosis in the COVID-19 patients is low compared to venous thrombosis, its implications or consequences can be devastating thus we should be alert to arterial thrombosis due to the new onset of hypercoagulable state in SARS-CoV-2 infection (2). Sometimes COVID-19 patients develop arterial thrombosis despite the antithrombotic prophylaxis (5). Antiaggregation therapy might be required due to the role of platelets in the arterial thrombus formation.

\section{CONCLUSION}

COVID-19 patients can develop arterial thrombosis as an infection presenting feature even without respiratory symptoms or fever. Thus, we should pay attention to this unusual and sometimes the only presentation of the SARSCoV-2 infection, that not only endangers the affected individual, but it could also cause the epidemiologic consequences with increased risk of viral transmission among vulnerable intrahospital population unless timely recognized. It is important that every patient presenting with arterial thrombosis, especially with floating thrombus, regardless of the typical COVID-19 symptoms absence, gets tested for SARS-CoV-2. The exact mechanism of the thromboembolism in COVID-19, like in majority of other infections, remains mostly controversial and needs further investigation.

The work was carried out in University Hospital of Split, Croatia, Spinčićeva 1,21000 Split. Data were extracted from electronic medical records.

\section{NOVČANA POTPORA/FUNDING \\ Nema/None}

\section{ETIČKO ODOBRENJE/ETHICAL APPROVAL \\ Nije potrebno/None}

\section{SUKOB INTERESA/CONFLICT OF INTEREST} Autori su popunili the Unified Competing Interest form na www.icmje.org/coi_disclosure.pdf (dostupno na zahtjev) obrazac i izjavljuju: nemaju potporu niti jedne organizacije za objavljeni rad; nemaju financijsku potporu niti jedne organizacije koja bi mogla imati interes za objavu ovog rada u posljednje 3 godine; nemaju drugih veza ili aktivnosti koje bi mogle utjecati na objavljeni rad./ All authors have completed the Unified Competing 
Interest form at www.icmje.org/coi disclosure. pdf (available on request from the corresponding author) and declare: no support from any organization for the submitted work; no financial relationships with any organizations that might have an interest in the submitted work in the previous 3 years; no other relationships or activities that could appear to have influenced the submitted work.

\section{LITERATURE}

1. Abobaker A, Raba AA, Alzwi A. Extrapulmonary and atypical presentations of COVID-19. J Med Virol. 2020; 10: 1002/jmv.26157.

2. Abou-Ismail MY, Diamond A, Kapoor S, Arafat Y, Nayak L. The hypercoagulable state in COVID-19: Incidence, pathophysiology, and management. Thromb Res. 2012; 194: 101-5.

3. Cantador E, Nunez A, Sobrino P, Espejo V, Fabia L, Vela L, et al. Incidence and consequences of systemic arterial thrombotic event sin COVID-19 patients. J Thromb and Thrombolysis. 2020; 9: 1-5.

4. De Carranza M, Salazar DE, Troya J, Alcázar R, Peña C, Aragón E, et al. Aortic thrombus in patients with severe COVID-19: review of three cases. J Thromb Thrombolysis. 2021; 51: 237-42. https://doi.org/10.1007/s11239-02002219-z.
5. Ferguson K, Quail N, Kewin P, Blyth KG. COVID-19 associated with extensive pulmonary arterial, intracardiac and peripheral arterial thrombosis. BMJ Case Rep. 2020; 13 (8): e237460.

6. De Roquetaillade C, Chousterman BG, Tomasoni D, Zeitouni M, Houdart E, Guedon A, et. al. Unusual arterial thrombotic events in COVID-19 patients. Int J Cardiol. 2021; 323: 2814. Published online 2020 Sep 10. doi:10.1016/j. ijcard.2020.08.103.

7. Vulliamy P, Jacob S, Davenport RA. Acute aorto-iliac and mesenteric arterial thromboses as presenting features of COVID-19. Br J Haematol. 2020; 189: 1053-4.

8. Mestres G, Puigmacia R, Blanco C, Yugueros X, Esturrica M, Riambau V. Risk of peripheral arterial thrombosis in COVID-19. J Vasc Surg. 2020; 72: 756-7.

9. Yin S, Huang M, Li D, Tang N. Difference of coagulation features between severe pneumonia induced by SARS-CoV2 and non-SARSCoV2. J Thromb Thrombolysis. 2020; 3: 1-4.

10. LaFree A, Lenz A, Tomaszewski C, Quenzer F. Case Report of Thrombosis of the Distal Aorta with Occlusion of Iliac Arteries in COVID-19 Infection. 2020. Clinical Practice and Cases in Emergency Medicine. Retrieved from https:// escholarship.org/uc/item/7wd5x 5jv.
11. Wickham H, Tam JCH, Chan XHS, George MJ, Levi M, Brown M. Aortic thrombosis in COVID-19. Clinical Infection in Practice, https://doi.org/ 10.1016/j.clinpr.2020.100059.

12. Goldman IA, Ye K, Scheinfeld MH. Lower extremity arterial thrombosis associated with COVID-19 is characterised by greater thrombus burden and increased rate of amputation and death. Radiology. 2020; 16: 202348.

13. Kasinanthan G, Sathar J. Haematological manifestations, mechanisms of thrombosis and anticoagulation in COVID-19 disease: A review. Ann Med and Surg. 2020; 56: 173-7.

14. Koupenova M, Kehrel BE, Corkrey HA, Freedman JE. Thrombosis and platelets: an update. Eur Heart J. 2017; 38: 785-91.

Sažetak

\section{MASIVNA TROMBOZA ABDOMINALNE AORTE S DISTALNOM EMBOLIJOM KAO JEDINA KLINIČKA MANIFESTACIJA COVID-19 INFEKCIJE}

Ivana Štula, Maja Marinović Guić, Sanja Lovrić Kojundžić, Jasenka Gabrić

Infekcija COVID-19 se obično manifestira respiratornim simptomima i vrućicom, no u literaturi je opisano nekoliko neuobičajenih početnih simptoma bolesti. Prikazujemo slučaj bolesnice s trombozom arterije kao jedinom kliničkom prezentacijom ove bolesti, bez drugih uobičajenih simptoma vezanih uz COVID-19. Ukoliko se pravovremeno ne prepozna, to može rezultirati odgođenim dijagnosticiranjem i izolacijom suspektnog bolesnika te uzrokovati epidemiološke posljedice i povećani rizik prijenosa virusa unutar bolnice u doba pandemije.

Ključne riječi: COVID-19, ARTERIJSKA TROMBOZA, AORTA, EMBOLIJA

Primljeno/Received: 22. 3. 2021.

Prihvaćeno/Accepted: 26. 4. 2021. 